\title{
Development Media Analysis in Financial Statements Learning Practices of Hospitality Entities Through Spreadsheet
}

\author{
Ni Luh Gede Erni Sulindawati \\ \{erni.sulindawati@undiksha.ac.id\} \\ Economics and Accounting Department, Universitas Pendidikan Ganesha, Singaraja, Indonesia
}

\begin{abstract}
This reserach is motivated by the discovery of the fact that students do not yet have sufficient competence in the practice of making financial statements of hospitality entities. One way to help facilitate student understanding needs to be developed as appropriate learning media. Media that can be developed in the practice of making financial statements of hospitality entities is a spreadsheet application. This application will be clearly illustrated the steps in making financial reports that facilitate student understanding. This research method used the development method at the stage of media development with qualitative analysis combined with the validity and reliability test of learning media developed with quantitative analysis. Data was collected through literature review, interviews, questionnaires for students who programed hospitality accounting courses, and with learning media assessment sheets from judges. The results shows that the validity and reliability test are valid and reliable.
\end{abstract}

Keywords: Learning Media, Financial Statements, Accounting, Hotel Entities, Spreedsheet

\section{Introduction}

In the era of globalization and the development of information technology which is so fast at this time required competence of graduates who are able to compete and to overcome the problems of information technology. To improve the competence of students who are able to compete one of the ways can be given education and training. Student competencies expected from graduates of accounting study programs as stated in learning outcomes are students' ability to practice financial reporting from various economic entities. The ability to prepare financial statements that are expected to be practiced by students in preparing financial reports for hospitality entities. The activities of the hospitality business in Indonesia and particularly in Bali continue to grow significantly. The courses in accounting studies related to hotel business are hospitality accounting. In accordance with the student study guidebook, after taking the hospitality accounting course, it is expected that the achievement of special skills is to apply accounting in various hotels[1]. The hotel business or tourism is established as a leading sector that requires all ministries to support tourism activities [2]. The statement was stated by the President of Indonesia (Mr. Joko Widodo) in a limited meeting [3]. As a leading sector in tourism, it is necessary to employ labor competencies as adequate and quality resources [3].

Hospitality accounting study in economics and accounting courses currently in the preparation of financial statements are still using the manual method. Financial statements are prepared through a long process that starts from making a journal of transactions proof, posted to the general ledger, proceed to the trial balance, work sheet, income statement, changes in equity, balance sheet and cash flow statement. 
In the tourism business there are USALI guidelines that uniform the process of making financial accounting reports. The Uniform System Of Accountants For Lodging Industry (USALI), this system provides several benefits such as (1) understanding uniformity of terms that are commonly applied to hotel business; (2) comparison of financial data for hotels of the same class; and (3) making time series data with the purpose of conflation and interpretation[3], [4].

To be able to improve the competency or ability of students in the practice of making financial statements of hospitality entities, learning media are needed that can facilitate student understanding. The media that can be used to facilitate the preparation of financial statements for hospitality entities is a spreadsheet application. Spreadsheet application can make it easier for students to understand the making financial statements steps of hospitality entities by utilizing the sheets in the application.

Based on statements, the research was analyzed and developed a learning media in the practice of making financial statements of hospitality entities through a spreadsheet application.

The problem formulation in this research is whether the learning media in the practice of making financial statements of hospitality entities through a spreadsheet application that is developed is valid and reliable applied in learning.

The purpose of this paper is to determine the learning media in the practice of making financial reports of hospitality entities through a spreadsheet application that is developed to be valid and realiable to be applied in learning.

\section{Literature Review}

Through this spreadsheet application can be made an accounting cycle by utilizing existing sheets. As an illustration, it can be made in the first sheet of the journal, the second sheet, etc. The general ledger corresponding to the accounts in the assets, passive, income and expense groups, the next sheet can be made a trial balance, adjusting entry, balance sheet, and financial statements. namely the income statement, changes statement in equity and balance sheet. In according with this learning media, it will be easier for students to understand the accounting cycle related to the practice of making financial reports. This learning process will be able to show real conditions in the field of work and the quality of learning is expected to be improved. Learning media is needed in the learning process carried out by educators. Various media can be used in transferring knowledge. Understanding media according to AECT is as all forms and channels that people use for messages or information [5]-[11]. In order for the learning process to be achieved in accordance with its intended purpose, students should be invited to make use of all the senses, the more sensory devices are used to receive and process information the more likely the information is understood and can be maintained in memory [7], [8], [10]-[13].

The existence of learning media as a tool in learning activities is a reality that cannot be denied, without the media, learning materials will be difficult to be understood by students, if the learning material that must be delivered is classified as complex, so the use of media absolutely must be done which that the subject matter can reach the students effectively and efficiently[8]-[11], [14]-[16]. According to Sadiman the use of media in learning has uses, among others: (1) clarifying the presentation of the mandate so as not to be too verbalistic, (2) overcoming limitations of space, time, power and senses, (3) the use of media properly and to be able to overcome the attitude passive students, and (4) the media can provide the same stimulants, equalize experiences, give rise to the same perception[6]-[8], [11], [14], [15]. From the description above the learning media is very important to increase student understanding which ultimately increases student competency.

In preparing the financial statements of hospitality entities, it is necessary to understand in advance the accounting treatment. The accounting treatment in the hotel sector is not much different from the accounting treatment in other sectors or other entities. The difference is that there are different characteristics of the income earned by the hospitality entity and the use of USALI guidelines in the format of preparing financial statements. The income earned by the hospitality entity can be in the form of room, restaurant, laundry, telephone and other services in accordance with the hospitality activities. The accounting treatment of hospitality entities concerns the aspects of recognition, measurement, presentation and disclosure of all estimates made based on generally accepted accounting principles. 
Based on financial accounting standards, there are four basic principles of accounting used in transactions, namely (1) the principle of historical costs (this principle requires the use of acquisition prices to record assets, debts, capital and costs); (2) the principle of revenue recognition in the principles there are two approaches taken, namely revenue is recognized if it has been realized (if the goods or services, or other assets have been exchanged for cash or claims on cash) or can be realized, (3.) the matching principle, shows that the amount of economic resource expenditure must be followed by the amount of economic source inflows to the entity which means that in each expenditure always takes into account the amount of benefits to be received; (4) the principle of full disclosure, the information contained in financial statements must be truly reliable so it can be used as a basis for decision making [17].

The financial statements for hospitality entities can be presented by following the standard guidelines used namely USALI which applies simultaneously to entities that are active in the hospitality world.

Making financial reports is needed to determine the performance and sustainability as well as the growth of the hospitality business. The complete financial statements consist of balance sheet, income statement, statement of changes in equity, cash flows statement, and notes to the financial statements [18], [19]. The financial statements must present fairly the financial position, financial performance, changes in equity, and the company's cash flow accompanied by disclosures in the notes to the financial statements which is accordance with applicable standards [18], [19]. The general presentation and disclosure process of hospitality accounting reports is almost the same as the financial accounting reports of other entities. The types of entities of a business can be divided into three, namely trading companies, service companies, and manufacturing companies. However, in the hospitality business there are guidelines that make the process of making financial accounting reports uniform, namely the USALI guidelines.

The financial position statement / balance sheet describes the financial position of an entity at a certain time, it can be days, weeks, months, quarterly, semester and year. The balance sheet is a financial portrait of a company or entity at certain times. The balance sheet illustrates the financial position and provides a description of the company's ability to generate revenue or profits[17].

The statement of changes in equity presents, among other things, entity's profit or loss for a period, income and expense items that are recognized directly in equity for the period, the effect of changes in accounting policies and correction of errors recognized in the period, the amount of investment, and dividends distributions to others, and the owner of equity during the period [18].

A cash flow report presents the relevant information about cash revenues and expenditures of a business unit in one period to the next period [20].

To be able to compile these financial statements, the first steps to compile these financial statements are required to prepare journals, ledgers, trial balances, adjusting entries, work sheet, and financial statements. Peoples can use the spreadsheet to make it easier.

\section{Methodology and Data Analysis}

The research design used in this study is a development method that is at the stage of developing instructional media in the practice of making financial reports in hospitality entities through spreadsheet applications and validity and reliability testing based on the ADDIE development model. one, Small group trials, and Field trials [21]. Research activities undertaken include management organizations, developing learning objectives, establishing learning strategies, instructional media used and requesting expert assessment of content, design, and material.

After developing the learning media development in the practice of making financial reports on hospitality entities through a spreadsheet application, the validity and reliability of the media developed was tested.

Learning media in the practice of making financial reports on hospitality entities that were developed were tested by three experts in the discussion called the Focus Group Discussion (FGD). In this focused discussion activity, the validity of the theoretically developed media was studied. The media component according to Joice et al (Joyce \& Weil, 2003) consists of (1) syntax, (2) social systems, (3) 
reaction principles, (4) support systems and (5) instructional and parenting effects. According to Marrelli, 2008 [22], FGD activities are small group discussions that answer a series of questions and suggestions that focus on a topic. According to Hennik [23], The FGD aims to identify various perspectives and gain understanding of the study theme from the perspective of the participants. In FGD, expert panel techniques are used. In this expert panel activity, experts who knew about the theme shared their knowledge in the discussion [22]. Discussion groups function like interview groups that ask a series of questions and each group member provides answers. This expert panel is an appropriate way to collect data about the validity of the media to create financial statements for hospitality entities through a spreadsheet media. The results of this group discussion are used as a guideline for revising learning media. The reliability of teaching media is evaluated based on the reliability of the content and the reliability of the organization in accordance with Nieveen's opinion [24]. Evaluation of content reliability is seen from six aspects of evaluation [25]-[27] as follows: The reliability of this media is determined by referring to the reliability criteria specified in Table 1.

Table 1. Evaluation Criteria for Learning Model Validation

\begin{tabular}{|c|c|c|}
\hline Interval Score & $\begin{array}{l}\text { Scoring } \\
\text { Criteria }\end{array}$ & Remarks \\
\hline $3.25<\mathrm{P} \leq 4.00$ & Very valid & Can be used without revision \\
\hline $2.50<\mathrm{P} \leq 3.25$ & Valid & Can be used with minor revisions \\
\hline $1.75<\mathrm{P} \leq 2.50$ & Less valid & Can be used with many revisions \\
\hline $1.00 \leq \mathrm{P} \leq 1.75$ & Invalid & $\begin{array}{l}\text { Not yet usable and still requires } \\
\text { consultation }\end{array}$ \\
\hline
\end{tabular}

Data about the reliability of teaching media was obtained from the teaching media on reliability sheets. This model reliability sheet is filled in by experts who study and evaluate teaching models developed by researchers at the Focus Group Discussion (FGD). The reliability of the instrument teaching model reliability sheet was established based on statistical analysis of the percentage agreement (R) (Borich, 1994). An instrument is said to be reliable when it has $\geq 75 \%$ [29].

\section{Research Result and Discussion}

4.1. Development of Learning Media in the practice of making hotel financial statements through a spreadsheet application

Learning Media in the practice of making hotel financial statements through a spreadsheet application containing the accounting cycle by utilizing existing sheets. As an illustration, it can be made in the first sheet of the journal, the second sheet and the general ledger that matches the accounts in the asset, passive, income and expense groups. The next sheet can be made a trial balance, adjustment journal entries, work sheet, and financial statements. namely the income statement, statement of changes in equity and balance sheet.

The steps in the practice of making financial statements include (1) analyzing transaction evidence, (2) keeping a journal, (3) posting a journal to general ledger, (4) preparing a trial balance from the balances in the general ledger, (5) make adjusting journals, (6) preparing work lanes or working papers, (7) prepare financial statements: consisting of income statements, statements of changes in equity and final balance sheets, (8) preparing closing journals, and (9) preparing a trial balance after closure and (10) analysis of hospitality financial statements. The steps in preparing the financial statements can be made through the Spreadsheet program or the Microsoft Excel program as illustrated below.

After an analysis of the transaction, a journal book is created which contains the Debit and credit columns, whereas transactions that repeatedly occur usually are not recorded in the Debit Credit journal, but are recorded in special journal books in columns. Journal books like this are specifically designed for recording certain transactions with regard to accounts that must be debited and credited. This method 
will reduce the work of keeping a journal and will facilitate the accounting of accounts. For transactions that do not occur frequently and are internal transactions, a general journal is created with a debit and credit column. Special journal books are usually made in pairs for transactions that often occur such as sales and receiving money journal books, purchase and expenditure journal and others.

To create a journal, people can use the Spreadsheet or the Microsoft Excel program. In this Program, the Date, Information, Ref, Debit and Credit columns are made. The date column is filled with the date when the transaction occurred, the information column is filled with the name of the account or estimate, the ref column is after the account is posted to the ledger, the debit and the credit column are filled with the amount of rupiah in accordance with the debit and credit rules of an account.

The stages of applying learning media to the practice of making financial statements of hospitality entities through this spreadsheet application consist of five stages which can be seen in Table 2 .

Table 2. Application Stages of Practical Learning Media for Making Financial Statements of Hospitality Entities Through Spreadsheet Application

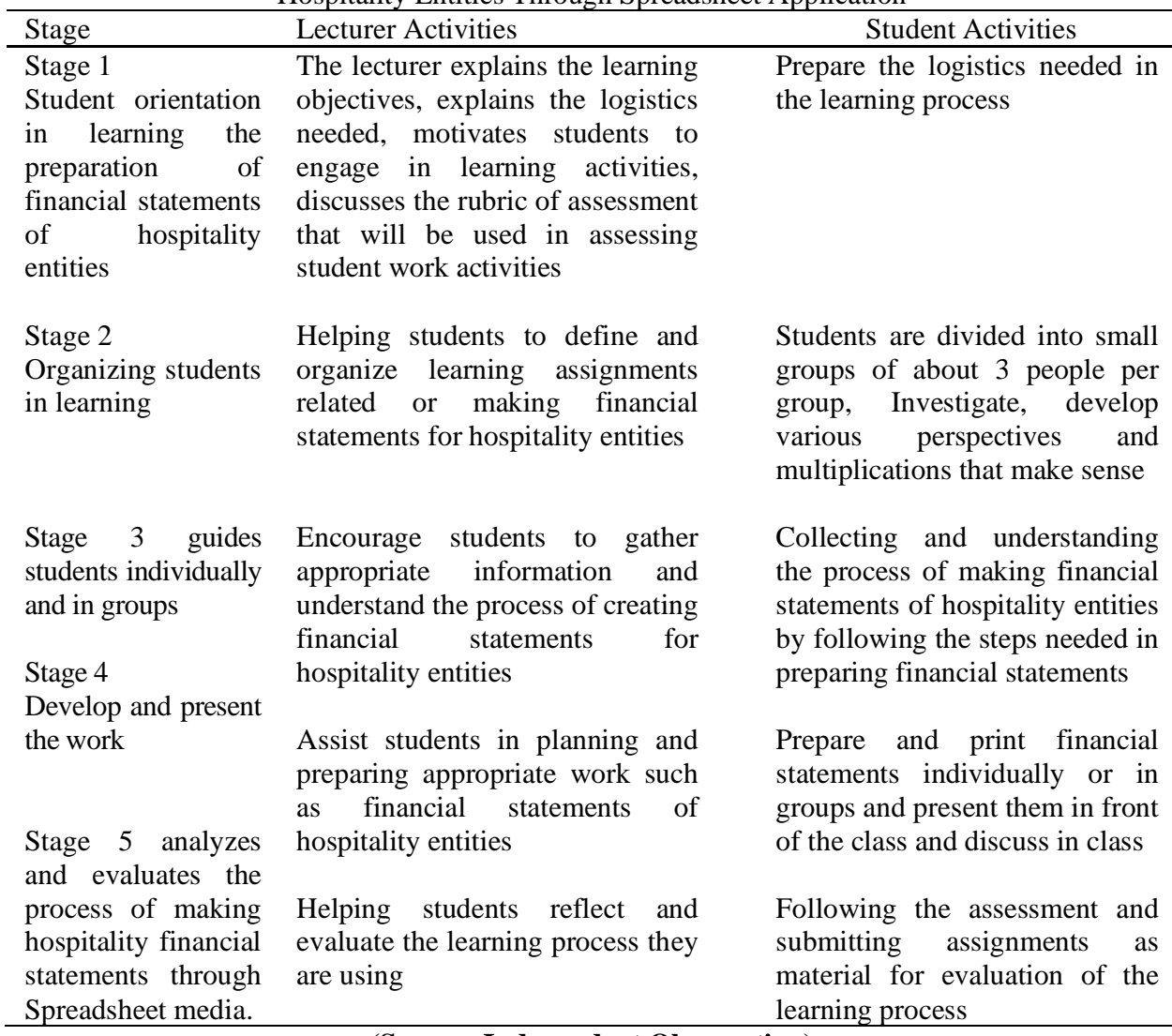

(Source: Independent Observation)

4.2. Validity and Reliability Test Results Development of Learning Media in the Practice of Making Hotel Financial Statements Through Spreadsheet Applications

After holding the FGD the results of the content and construct validation are in accordance with tables 3 and 4 . 
Table 3. Validity Content in The Learning Media Making Financial Statements Practice of Hospitality Entities Through A Spreadsheet Application

\begin{tabular}{|c|c|c|c|c|c|}
\hline NO & $\begin{array}{l}\text { Learning } \\
\text { Elements }\end{array}$ & $\begin{array}{l}\text { Validation } \\
\text { Score }\end{array}$ & Validity & $\mathrm{R}$ & Reability \\
\hline 1 & $\begin{array}{l}\text { Learning Media Development } \\
\text { Needs }\end{array}$ & 3.39 & Very Valid & $95.4 \%$ & Reliable \\
\hline 2 & $\begin{array}{l}\text { Current knowledge (State of the art } \\
\text { of knowladge), }\end{array}$ & 3.32 & Very Valid & $93.2 \%$ & Reliable \\
\hline 3 & $\begin{array}{l}\text { Theoretical and Empirical Support of } \\
\text { Learning Media }\end{array}$ & 3.32 & Very Valid & $88.8 \%$ & Reliable \\
\hline 4 & $\begin{array}{l}\text { Planning and Implementation of } \\
\text { Learning Media }\end{array}$ & 3.27 & Very Valid & $90.9 \%$ & Reliable \\
\hline 5 & $\begin{array}{l}\text { Learning Environment Learning } \\
\text { Media }\end{array}$ & 3.12 & Very Valid & $90.9 \%$ & Reliable \\
\hline 6 & $\begin{array}{c}\text { Use of Evaluation Techniques } \\
\text { Average }\end{array}$ & $\begin{array}{l}3.20 \\
3.27\end{array}$ & $\begin{array}{l}\text { Very Valid } \\
\text { Very Valid }\end{array}$ & $\begin{array}{l}87.5 \% \\
91.1 \%\end{array}$ & $\begin{array}{l}\text { Reliable } \\
\text { Reliable }\end{array}$ \\
\hline
\end{tabular}

(Source: Independent Observation)

The learning media content validity in the making financial statements practice of hospitality entities through a spreadsheet application that was developed shows the results of a very valid category in terms of several aspects of assessment, namely the need for developing learning media, state of the art knowledge, the theoretical and empirical support that underlies learning media, planning and implementing learning media, learning environment, and using evaluation techniques. The percentage of agreement of the content validation assessment is classified as reliable with an $\mathrm{R}$ of $91.1 \%$.

Tabel 4 . The Instructional Media Construct Validity Of Making Financial Statements Practice Of Hospitality Entities Through A Spreadsheet Application

\begin{tabular}{|c|c|c|c|c|c|}
\hline NO & Learning Media Elements & $\begin{array}{l}\text { Validation } \\
\text { Score }\end{array}$ & Validity & $\mathrm{R}$ & Reabil \\
\hline 1 & $\begin{array}{l}\text { Learning Media Needs of the practice } \\
\text { of making financial statements for } \\
\text { hospitality entities }\end{array}$ & 3.25 & Ver & $.7 \%$ & \\
\hline 2 & $\begin{array}{l}\text { ical and Empirical Support of } \\
\text { g media }\end{array}$ & 3.29 & Very Valid & $88.1 \%$ & Reliable \\
\hline 3 & $\begin{array}{l}\text { Planning and Implementation of } \\
\text { Learning Media }\end{array}$ & 3.33 & Very Valid & $93.8 \%$ & Reliable \\
\hline 4 & $\begin{array}{l}\text { Learning Environment and Learning } \\
\text { Media }\end{array}$ & 3.20 & Very Valid & $87.5 \%$ & Reliab \\
\hline 5 & & 3.17 & & & \\
\hline 6 & $\begin{array}{c}\text { Media: A final t } \\
\text { Average }\end{array}$ & $\begin{array}{l}3.24 \\
3.25\end{array}$ & $\begin{array}{l}\text { Very Valid } \\
\text { Very Valid }\end{array}$ & $\begin{array}{l}89.6 \% \\
89.9 \%\end{array}$ & $\begin{array}{l}\text { Reliable } \\
\text { Reliable }\end{array}$ \\
\hline
\end{tabular}

(Source: Independent Observation)

The instructional media construct validity of making financial statements practice of hospitality entities through a spreadsheet application. Learning media elements assessed are the needs of Learning Media in making financial statements practice of hospitality entities, theoretical and empirical support of learning media, planning and implementation of learning media, learning environment media, and the use of evaluation techniques, learning media: a final thought. Percentage of agreement obtained $89.9 \%$ results are classified as reliable. 


\section{Conclusion}

Based on the results of the above research it can be concluded that the learning media of making financial statements practice of hospitality entities through a spreadsheet application that was developed is classified as very valid so that it can be used and implemented in the learning process. This media needs to be tested for practicality and effectiveness in learning.

\section{Implications and Suggestions for Further Research}

Reliable and validity test results show that learning media making practices in the financial statements of hospitality entities through a spreadsheet application, the developed media can be tested in the pilot phase both on a small scale and large scale, to get input and suggestions for improving the media being developed. This learning media, it is expected to help facilitate students in understanding the practice of making financial statements for hospitality entities. For further research, the media can use the spreadsheet in preparing financial reports on other types of businesses.

\section{References}

[1] Undiksha, "Pedoman Studi Fakultas Ekonomi-Undiksha." 2016.

[2] N. W. G. Adnyani, "Tourism Education For All: Indonesia Perspectives," 2019.

[3] N. Sulindawati, L. Musmini, and N. Trisna Dewi, "Analyzing the Need to Develop Materials in the Teaching of Hotel Accounting that Meet the Requirements of the Graduate Users," vol. 103, no. Teams 19, pp. 122-125, 2019.

[4] Dodik Ariyanto, dkk“Laporan Penelitian," 2014.

[5] Anjar, "Pengertian Media Pembelajaran,"

https://www.wawasanpendidikan.com/2015/10/pengertian-media-pendidikan-menurutahli.html, 2015. .

[6] R. Arief S. Sadiman, R. Rahardjo, Anung Haryono, Media Pendidikan. 2007.

[7] M. Harahap and L. M. Siregar, "Mengembangkan sumber dan media pembelajaran," Educational, no. January, p. 10, 2018.

[8] N. Mahnun, "Media Pembelajaran (Kajian terhadap Langkah-langkah Pemilihan Media dan Implementasinya dalam Pembelajaran)," J. Pemikir. Islam., vol. 37, no. 1, pp. 27-35, 2012.

[9] A. Muhson, "Pengembangan Media Pembelajaran Berbasis Teknologi Informasi," J. Pendidik. Akunt. Indones., vol. 8, no. 2, 2010.

[10] T. Tafonao, "Peranan Media Pembelajaran Dalam Meningkatkan Minat Belajar Mahasiswa," J. Komun. Pendidik., vol. 2, no. 2, p. 103, 2018.

[11] J. A. Yulianto, "Makalah Pendidikan," https://olinlakoro.wordpress.com/, 2011. [Online]. Available: https://pandidikan.blogspot.com/2011/05/kualitas-pendidikan.html.

[12] Azhar Arsyad, Media Pembelajaran. Raja Grafindo Persada Jakarta. 2007.

[13] U. Fadhilatunnisa, "Pengaruh Media Pembelajaran Mind Map Terhadap Pemahaman Konsep Belajar Peserta Didik Di Sma Angkasa Tahun Ajaran 2016/2017 (Studi Kasus Pada Peserta Didik Kelas X MIPA Mata Pelajaran Ekonomi Lintas Minat)," http://repository.unpas.ac.id/29080/5/14.\%20BAB\%202.pdf, 2017. .

[14] H. Susanto, "Media Pembelajaran Dalam Menullis Puisi," https://bagawanabiyasa.wordpress.com/2015/11/24/media-pembelajaran-menulis-puisi/, 2015.

[15] N. Wadiah, "Teknologi Media Pembelajaran," http://nurulwahdiah234.simplesite.com/, 2015.

[16] P. Widyanto, "Media pembelajaran," https://putuwidyanto.wordpress.com/2011/01/14/mediapembelajaran/, 2011.

[17] J. Badruzaman and D. Kusmayadi, Akuntansi Hotel, no. May 2014. 2014.

[18] Ikatan Akuntan Indonesia, Standar Akuntansi Keuangan ETAP. 2009.

[19] Witdya Pangestika, "Laporan keuangan," https://www.jurnal.id/id, 2020.

[20] N. Sulindawati, "An Analysis of Instructional Material Need For Improving Students ' Ability in Writing Cash Flow Reports," vol. 134, no. Icirad, pp. 146-152, 2017. 
[21] M. M. Adha, "Model Pengembangan Pembelajaran Pendididikan Kewarganegaraan Berbasis Multikultur Dalam Rangka Menanamkan Nilai-Nilai HAM dan Demokrasi," J. Media Komun. FIS, vol. 12, pp. 1-16, 2012.

[22] Marrelli, "Collecting Data Through Focus Groups. Performance Improvement," 2008.

[23] H. Jakobsen, "Hilde Jakobsen," Qual. Res., vol. 12, no. 2, pp. 111-130, 2012.

[24] N. Nieveen, "Prototyping to Reach Product Quality. In Akker, J. V. D., Branch, R. M., Gustafson, K., Nieveen, N., dan Plomp, T. (Eds), Design Approaches and Tools in Education and Training (pp. 125-135). Dordrecht, Netherlands: Spinger." 1999.

[25] R. I. Arends, "). Learning to Teach (nineth edition).," in Learning to Teach (nineth edition). New York: Mc. Graw -Hill Companies, Inc, 2012.

[26] Nieveen, N., McKenney, S., Educational Design Research dalam Educational Design Research. New York: Routledge. 2007.

[27] B. Joyce and M. Weil, Models of Teaching. 5th Edition: Pearson Education Inc. 2003.

[28] Suherman, "Analisis implementasi kebijakan pendidikan karakter," J. Adm. Pendidik., vol. 21, no. 2,2014

[29] G. Borich, "Observation Skill for Effective Teaching," in Observation Skill for Effective Teaching New York: Mac Millan Publishing Company, 1994. 